\title{
History, Present and Expected Future of Forests in Slovakia
}

\author{
Gubka Andrej ${ }^{1}$, Nikolov Christo ${ }^{1}$, Gubka Karol ${ }^{2}$, Galko Juraj $^{1}$, Vakula Jozef ${ }^{1}$, Kunca Andrej ${ }^{1}$, \\ Leontovyč Roman ${ }^{1}$
}

${ }^{1}$ National Forest Centre-Forest Ressearch Institute, Zvolen, Slovak Republic; ${ }^{2}$ Faculty of Forestry, Technical University, Zvolen, Slovak Republic.

Email: gubka@nlcsk.org

Received January $5^{\text {th }}, 2013$; revised February $11^{\text {th }}, 2013$; accepted February $22^{\text {nd }}, 2013$

\begin{abstract}
In this paper, we briefly summarize the problems that have been affecting Slovakian forestry in the past, in the present and are expected in the future. In the past, the forests in Central Europe were significantly harmed by the development of mining, metallurgy, wood processing industry, agriculture and grazing of sheep and cattle. Many areas have been completely deforested. Fundamental change occurred in the $18^{\text {th }}$ Century, when the regulations about forest management, declared by Empress of the Austro-Hungarian monarchy Maria Therese, came into force. With the changing level of forest cover, there have been changing as well the problems in the forestry. Forests in Slovakia are nowadays dealing with the climate change, which is causing extreme weather fluctuations. It is connected with the emergence of abiotic disturbances after which usually occurs activation of biotic harmful agents. We expect that the most serious problem of forests in the future will be their state of health. We expect an increase representation of thermophilic tree species (beech and oak) at the expense of upland trees such as spruce. An important role will be played by the invasive species of plants, fungi and animals that can compete with native species and their habitats or in the situation of the absence of their reducents these can cause serious economic and environmental damage.
\end{abstract}

Keywords: History of Forestry; Forest Pests; Climate Change; Future of Forests; Bark Beetles

\section{Introduction}

Slovakia is a small country in the centre of Europe with forest cover of more than $40 \%$. It is $11^{\text {th }}$ from 50 European countries regarding the area of forest cover [1]. However, this was not always the case and forestry passed a long way to achieve its current form. Over time, the forests in Slovakia have been changing and used in different ways. From almost total forest cover we have undergo a period of extreme devastation of forests through the initial efforts of protection of forests and forest land to the current planned forest management, with close to nature management efforts.

The aim of this paper is to give a brief overview of past, present and expected problems of forestry in Slovakia.

\section{Excessive Logging in the Past and the Beginnings of Forestry}

At the beginning of $11^{\text {th }}$ century, the territory of presentday Slovakia was made part of Kingdom of Hungary, later Austro-Hungarian monarchy. The action of rulers of these countries significantly affected forests and forestry in Slovakia. The forest began to be emphasized in the $13^{\text {th }}$ century, with the intensification of colonization of Slovakia. The process was advanced by the raids of the Tatar hordes in 1241-1242, which drove the inhabitants of the lowlands to seek the safety in the mountains [2]. During this period, people used forests mostly to satisfy their own needs, and turn the land into fields, meadows and pastures. The King of Hungary Béla IV subsequently invited citizens of German countries (German colonists) with knowledge of a particular field; agriculture, mining, metallurgy, charcoal making and wood processing to depopulated areas of present-day Slovakia [3]. The country's rich mineral resources were in $13^{\text {th }}$ and $14^{\text {th }}$ century connected with the intensive development of mining and metallurgy. Because of fuel needs, this led to deforestation around mining centres and consequently contributed to depletion of forest cover along river banks.

Even more forest damage was caused by immigrants, Roman-speaking Valachs, coming from the Eastern Carpathians. The Migration period may be divided into two periods, the first, occurring between $13^{\text {th }}-14^{\text {th }}$ century, 
and the second phase, which took place between $16^{\text {th }}$ until the beginning of $17^{\text {th }}$ century. Since 1465 these migrants were exempt from taxes and later on they profited of various privileges such as herding their livestock on the mountain meadows or slash-and-burn agriculture. For the purposes of grazing sheep and goats the large tracts of forests have been destroyed even on mountain ridges. In some places the upper forest border is missing until now [3].

The impact of these activities is well documented by the data from Slovakian northern region Orava. It is reported that the forest that had originally covered $90 \%$ of the total area of the Orava, covered at the end of the $18^{\text {th }}$ century just over one-third. With the increase of human population, the area of the forest started to diminish as a result of demand of the land. In the $13^{\text {th }}$ century in the Orava region there were 10 villages with the population of 2000 to 3000 . In the $18^{\text {th }}$ century (1777) the number of villages increased to 96 with the population of 63,628 people [4].

In the $15^{\text {th }}$ and $16^{\text {th }}$ century inhabitants and rulers began to feel the lack of wood and forests. This led to a rift between the forest owners and situation resulted to a decline in metallurgy and mining of noble metals. In these conditions were implemented the local control rules and regulations. In particular, in 1426 the King Sigismund established new order in the Zvolen county. He forbade shifting cultivation and ordered annual clearing and reforestation. This is the first regulation in the territory of present-day Slovakia with an effort to prevent deforestation [5].

The forest code issued by Emperor Maximilian II as a "forest policy" (Constitutio Maximilian) in 1565 was a landmark in the history of regulating woodcutting and other forest activities. Its adoption marked the beginning of forestry as a controlled activity and helped to stabilize forests and forestry practices. The Code comprised 30 articles regulating various forestry activities, including cutting under supervision of experienced masters, felling practices, the storage of wood during the winter season, leaving seed trees, etc. [2]. Application of all this regulations in practice received little attention, and the problem with grazing sheep and goats persisted long after this statute [3].

A fundamental breakthrough occurred in 1754-1769, when an extensive forest inventory was made. In 1769 during the reign of Empress Maria Theresa a new Forest Code known as Sylvarum conservadarum et lignicidii ordo [2] was issued. The Theresian Forest Code identified the following three principal goals:

- to define what rules to observe during tree felling;

- to set a method of cultivating new forests;

- to identify the means of achieving permanent benefits from the forests [2].
These orders provided the framework for sustainable forest management and were applied to any land within the boundary of the forest.

From the initiative of Maria Theresa, in 1762, the world's first mining academy was founded in the town of Banská Štiavnica. It was the first technical college in the world and it brought Banská Štiavnica the status of the centre of mining science and technology development in Europe. In 1770 she approved the proposal putting appropriate attention to the forestry subject. Apart from the Forestry discipline, the study of Wood Processing was also provided. Further improvement of the forestry education in Banská Štiavnica is connected with the establishment of the Forestry Institute in 1807 by Francis I. $[6,7]$.

The first Forest Act in Austro-Hungarian Empire came into existence in 1879 (XXXI/1879), and with partial adjustment was valid in Slovakia until 1960 [3].

\section{Current Status and Problems in Forests of Slovakia}

Since 1950, the forest holdings area has been steadily increasing. According to last report the area of forest crop land covers is $1,938,904$ hectares which is approximately $40.9 \%$ of the total area of Slovakia [8]. Slovak's forest cover has increased by more than $9 \%$ in 60 years. Conifer covers $40.5 \%$ and broadleaf $59.7 \%$ of forest land. The most abundant tree species include Fagus sylvatica (31.4\%), Picea abies (25.7\%) and Quercus sp. (13.3\%) [8]. The National Inventory and Monitoring of Forests (NIMF) are based on the selective statistical survey methods according to criteria of FAO. The first cycle of NIMF was performed in 2005-2006 and covered also forest vegetation on non-forest land. The inventory results put the area of forests on non-forest land at 275,000 ha $\pm 3.7 \%$, so the area of the forest covers about $44 \%$ [9]. A high proportion of forest on non-forest land is mainly due to a significant decline of agriculture in Slovakia.

Complex influence of injurious agents affecting in parallel or subsequently is the most important problem in the forest protection [10]. Data on the presence of harmful agents are sent annually by forest managers (regardless of ownership) to National Forest Centre [11]. As it is illustrated in the Figure 1 the incidental felling represents more than $50 \%$ of total annual felling. Windstorms have significant impact on Slovak forests. During the 1996 , about 1.5 mil. $\mathrm{m}^{3}$ of wood was damaged and in the 2004 approximately $5.3 \mathrm{mil} . \mathrm{m}^{3}$, mostly in spruce forests. After windstorm 2004 the bark beetle damages in coniferous forests rapidly increased and the current outbreak is the largest and most severe in recorded history (Figure 2). The most important forest pest in Slovak forests is the European spruce bark beetle (Ips typographus). During 


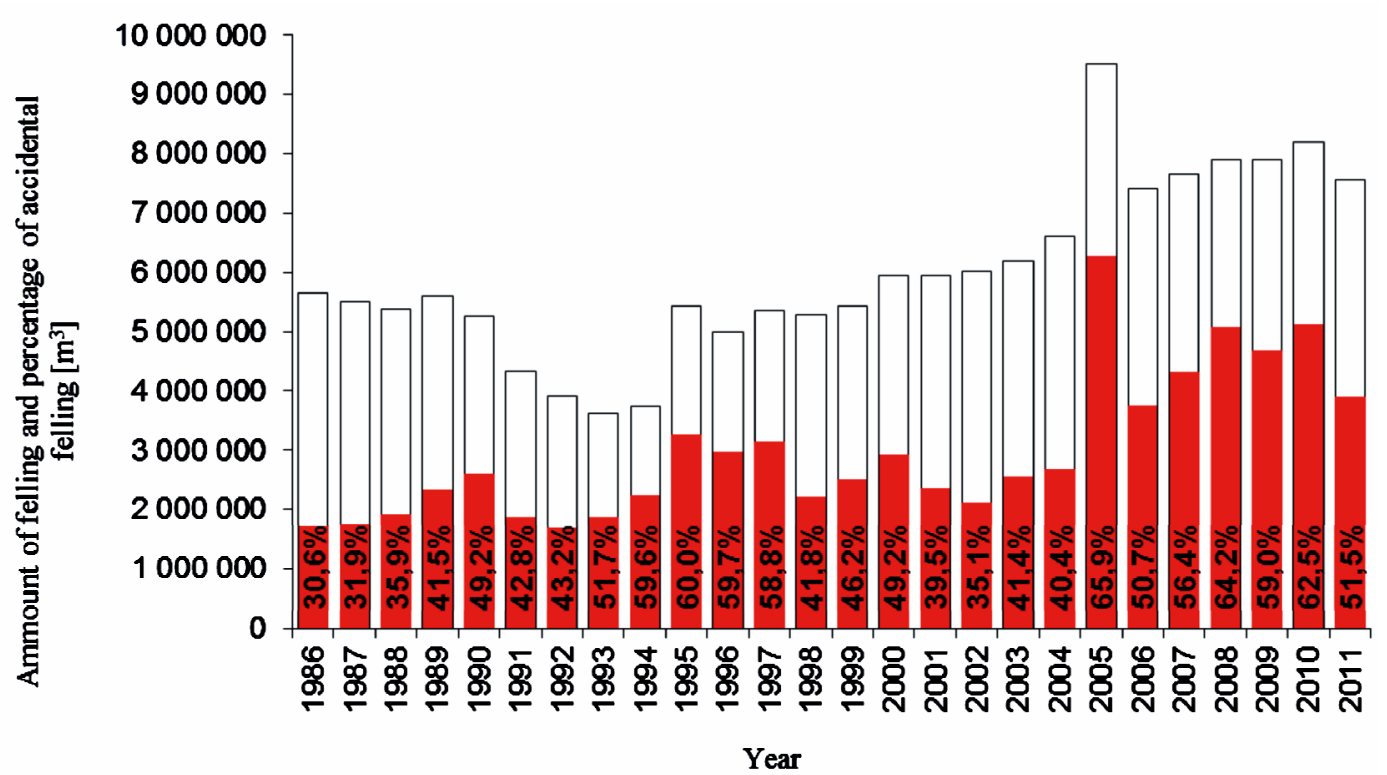

Figure 1. The annual share of accidental felling in total timber harvesting for years 1993-2011.

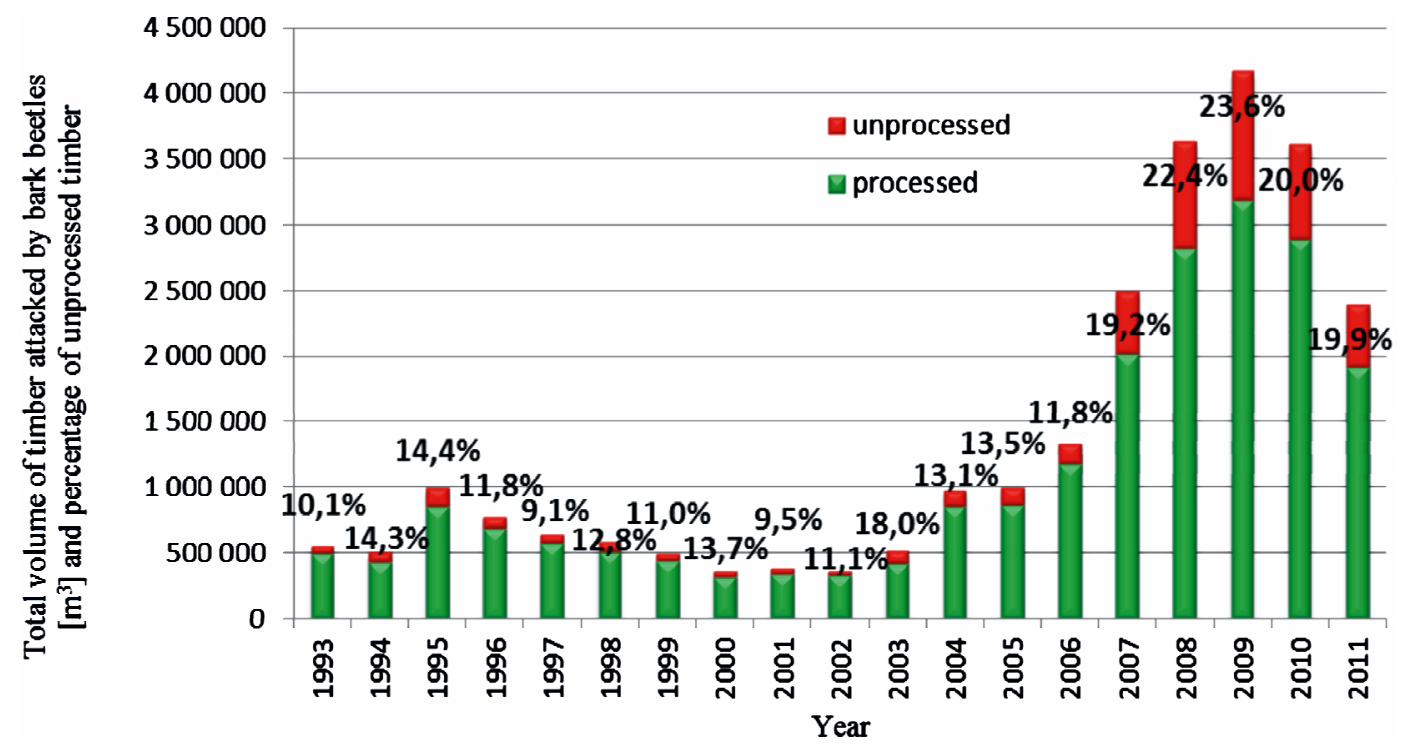

Figure 2. Annual volume of processed and unprocessed wood damaged by bark beetles in years 1993-2011.

the period 2005-2010, bark beetles damaged the forest three times more compared to the windstorm 2004. In some areas (High Tatra National Park) bark beetles destroyed more than $25 \%$ of the spruce forest [12]. As the result of windstorms and following bark beetle outbreaks the spruce is progressively replaced by beech in foothill areas.

The spruce stands are being damaged by a variety of harmful agents. Most of the regions with bark beetle outbreaks corresponded with those affected by the storm $[13,14]$. The dynamics of an outbreak largely depends on weather, drought periods, further storms or other stressors, as well as the availability and susceptibility of host plants $[15,16]$. Powerful windstorms and severe drought in 2003 and 2007 [17] triggered largest bark beetle outbreak in Slovakia ever recorded. As a consequence of severe drought in the northwestern parts of Slovakia the impact of Armillaria spp. on spruce stands increased. These stands were often planted in the genetically unsuitable habitat and non-adapted genetic material to specific mountain conditions was used $[18,19]$. Widespread deterioration in spruce monocultures associated with Armillaria spp. is to some extent accelerated by evenaged stands which can be more vulnerable to diseases, insect attack and changes in climate [20].

In 2002 a new Act about Protection of Nature and 
Landscape (No. 543/2002) was launched. The act restricts forest management on the areas with certain degree of nature conservation. Hence, calamity wood clearing at the nature conservation areas can be done only if special permission is issued by the Ministry of Environment of the Slovak Republic. However, process of issuing the permission is rather slow, postponing the forestry activities lowers efficiency of the measures.

The unprocessed windfalls infested by bark beetles represent suitable conditions for their dispersal and following outbreaks (Figure 2).

Much effort is put to slow down and reverse the increasing trend of damages caused by pests, and to bring the legislation towards finding optimal solutions with respect to the principles of nature conservation and forest management. However, despite these efforts, the process of bringing up the issues that forestry faces is slow due to the different interests of various stakeholder groups.

\section{Expected Problems in Future}

Implementation planning and close to nature forest management has been one of the main reasons for maintaining and increasing forest cover in the Slovak Republic. At a time when the whole world is trying to greening the economy, there is little likelihood that the European legislation will change so dramatically to enable higher logging than the annual increment, thus causing undesired reduction of forest cover.

A serious problem in the future will be global climate change and related disturbance. They directly affect the biota in all the world's ecosystems $[21,22]$. The effect of greenhouse gases is well documented also in Slovakia. In the years 1901-2008 was a temperature increase of 1.41 ${ }^{\circ} \mathrm{C}$ and annual rainfall decreased by $3.38 \%$ [23]. More frequent extreme weather events occur that are not typical for our area. For example, the 12 warmest years have been recorded since the early 90 's of last century. Similarly, the increasing frequency of extreme daily precipitation totals, resulting in a floods $[24,25]$. We assume that climate change will be a major factor in changes in forest ecosystems. Long-time droughts have stressful impact on forest trees and reduce their natural defenses [26]. Arising floods, droughts or wind and snow storms disrupt the static stability of forest stands.

Forests and silvicultural activities will gradually adapt to changing situation. Norway spruce (Picea abies) slowly recedes from lower altitudes and in mountainous areas are purposefully replaces by beech (Fagus sylvatica) and other deciduous trees suitable for this habitat. We expect a gradual increase in the representation of oak (Quercus spp.) in the forest. These processes will be accelerated by abiotic disturbances with subsequent activation of forest pests.
With a changing climate and a developed timber trade is also related the problem of invasive species. Invasive species of plants, fungi and animals already cause economic and environmental damage to forests. An example would be Ips duplicatus, which spread out to Slovakia at the end of the $20^{\text {th }}$ century and became a competitor of indigenous species (Ips typographus, Ips amitinus, Pityogenes chalcographus) [27]. Fungus Chalara fraxinea causes areal ash dying In Slovakia and also in other European countries [28]. As an example of invasive species spreading in recent years is Xylosandrus germanus, which was first discovered in Slovakia in 2010 and by observing his quantity grows sharply [29]. Effects of invasive species could threaten the future existence of protected species and the stability and functional effectiveness of habitats in our area.

The National Strategy on Invasive Species in Slovakia was carried out as a reaction to introduction and establishment of non-native species in our country and is based on the EU Strategy on Invasive Species. The strategy's goal is to raise public awareness about invasive species, to identify these species, to help in preparing legislation and improve interstate exchange of information on invasive species. As part of the prevention the strategy focuses on the tightening of border controls and quarantine measures, on developing an early warning system for new non-native invasive species, to reduce threats to natural ecosystems and to help preserve and restore native habitats.

\section{Summary}

Forests in Slovakia, more than in other Central European countries, has been for a long time intensively used primarily for the needs of agriculture, metallurgy and minfessional forestry has stopped quick decline of forests and subsequently reforest most of deforested areas. As a result of forestry activities in Slovakia is annual growing forests area. But it is also necessary to adapt forest management to changing conditions. From preference of timber production, we should switch our effort to non-productive functions of forests such as soil and water protection, recreational function and so on. However, it is essential that the public needs to be aware of forests importance and the need of professional, targeted and long-term management and to support the creation of suitable legal and financial conditions.

\section{Acknowledgements}

This work was supported by the Slovak Research and Development Agency under the contract No. APVV0045-10.

This research had been funded by the Operational Program of Research and Development and co-financed 
with the European Fund for Regional Development (EFRD). Grant: ITMS: 26220220109 Prognostic information systems for improving the efficiency of forest management $(50 \%)$.

\section{REFERENCES}

[1] FAO, "Global Forest Resources Assessment 2010 Main Report," 2010, p. 340.

[2] J. Mind'áš, J. Konôpka, J. Novotný and S. Jendek, "The Forests of Slovakia," National Forest Centre, p. 223.

[3] K. Gubka, "Kde Hl'adat' Základné Východiská Pestovania Lesa?" Les a letokruhy, No. 11-12, 2012, pp. 20-23.

[4] A. Kavuljak, “Oravský Komposesorát,” ŠL ČSR, p. 195.

[5] P. Maliniak, "O Aktuálnych Problémoch Lesníckej Histografie (s príKladmi zo Zvolenskej Stolice)," Z Dejín vedy a Techniky Stredoslovenského Regiónu, ÚVV UMB Banská Bystrica, 2009, pp. 16-24.

[6] J. Urgela, "Dejiny Lesníckeho Školstva a Vedy na Slovensku," Martin, Osveta, 1985.

[7] J. Urgela, "Výučba Lesníctva na Banskoštiavnickej Akadémii," Zborník Prednášok: 230 Rokov Baníckej Akadémie v Banskej Štiavnici, Košice, Banícka Fakulta TU Košice, 1992.

[8] Zelená Správa, "Správa o Lesnom Hospodárstve SR za Rok 2010, Zelená Správa,” Ministerstvo Pôdohospodárstva a Rozvoja Vidieka Slovenskej Republiky, p. 84.

[9] Š. Šmelko, V. Šebeň, M. Bošel'a, J. Merganič and J. Jankovič, "Národná Inventarizácia a Monitoring Lesov SR 2005-2006, Základná Koncepcia a Výber zo Súhrnných Informácií," NLC-LVÚ Zvolen, 2008, p. 15.

[10] J. Novotný, "Ekologizácia Metód Ochrany Lesa Proti Hmyzu," Ekologické Obhospodarovanie Lesov pre Ich Nepretržitý Rozvoj. Zborník Referátov z Konferencie, Zvolen, Október, 1995, pp. 81-85.

[11] A. Kunca, S. Find'o, J. Galko, A. Gubka, P. Kaštier, B. Konôpka, J. Konôpka, R. Leontovyč, V. Longauerová, Ch. Nikolov, J. Novotný, J. Vakula and M. Zúbrik, "Problémy Ochrany Lesa v Roku 2011 a Prognóza na Rok 2012," In: Kunca, Ed., Aktuálne Problémy v Ochrane Lesa 2012, Zborník Referátov z Medzinárodnej Konferencie Aktuálne Problémy v Ochrane Lesa, 2012. pp. 5-11.

[12] Ch. Nikolov, J. Ferenčík, M. Kajba, A. Gubka and A. Kunca, "The European Spruce Bark Beetle, Ips typographus (L.) Outbreak in High Tatra Mountains: Case Study (2005-2011)," In: Fleischer, Ed., Windstorm reSearch, 2012.

[13] W. Grodzki, "Some Reactions of Ips typographus (L.) (Col.:Scolytidae) to Changing Breeding Conditions in a Forest Decline Area in the Sudeten Mountains, Poland," Journal of Pest Science, Vol. 77, No. 1, 2004, pp. 43-48. doi:10.1007/s10340-003-0026-1

[14] B. Økland and A. Berryman, "Resource Dynamic Plays a Key Role in Regional Fluctuations of the Spruce Bark Beetles Ips typographus," Agricultural and Forest Entomology, Vol. 6, No. 2, 2004, pp. 141-146. doi:10.1111/j.1461-9555.2004.00214.x
[15] E. Christiansen and A. Bakke, "Does Drought Relay Enhance Ips typographus Epidemics?-A Scandinavian Perspective," Integrating Cultural Tactics into the Management of the Bark Beetle and Reforestation Pests, 1997 pp. 163-171.

[16] B. Wermelinger, "Ecology and Management of the Spruce Bark Beetle Ips typographus-A Review of Recent Research," Forest Ecology and Management, Vol. 202, No. 1-3, 2004, pp. 67-82. doi:10.1016/j.foreco.2004.07.018

[17] Z. Sitková, T. Hlásny, T. Vida, R. Sitko and P. Fleischer, "Analýza Klimatických Pomerov Vysokých Tatier v Súvislosti s s Vetrovou Kalamitou v Novembri,” In: B. Konôpka, Ed., Výskum Smrečín Destabilizovaných Škodlivými Činitel'mi, NLC, LVÚ, Zvolen, 2004, pp. 249-266.

[18] A. Krajčovič, "Návrh Zásad pre Obnovu a Výchovu Porastov v Oblasti TANAP-u," Conference, Vol. 11, 1998, p. 45.

[19] M. Stolina, "Ochrana Lesných Ekosystémov TANAP-u," Zborník Príspevkov z Konferencie pri Príležitosti 40 Výročia Uzákonenia TANAP-u, 1989, pp. 136-149.

[20] E. Klimo, H. Hager and J. Kulhhavý, "Spruce Monocultures in Central Europe-Problems and Prospects," EFI Proceedings 33, European Forest Institute, 2000, p. 208.

[21] P. M. Vitousek, "Beyond Global Warming: Ecology and Global Change," Ecology, Vol. 75, No. 7, 1994, pp. 18611876. doi: 10.2307/1941591

[22] G. R. Walther, E. Post, P. Convey, A. Menzel, C. Parmesan, T. J. C. Beebee, J. M. Fromentin, O. Hoegh-Guldberg and F. Bairlein, "Ecological Responses to Recent Climate Change," Nature, Vol. 416, 2002, pp. 389-395. doi:10.1038/416389a

[23] P. Faško, P. Lapin, M. Melo and J. Pecho, "Changes in Precipitation Regime in Slovakia-Past, Present and Future," 2nd International Conference on Bioclimatology 2009: A Changing Climate for Bilolgy and Soil Hydrologyinteracitons, Institute of Hydrology SAS, Bratislava, 21-24 September 2009.

[24] SHMU, "Slovak Hydrometeorological Institute, Prejavy Klimatickej Zmeny na globáLnej Úrovni”. http://www.shmu.sk/sk/?page=1379

[25] P. Faško, M. Lapin and J. Pecho, "20-Year Extraordinary Climatic Period in Slovakia," Meteorologický Časopis, Vol. 11, 2008, pp. 99-105.

[26] W. J. Mattson and R. A. Haack, "The Role of Drought in Outbreaks of Plant-Eating Insects," BioScience, Vol. 37, No. 2, 1987, pp. 110-118. doi:10.2307/1310365

[27] J. Vakula, A. Kunca, M. Zúbrik, R. Leontovyč, V. Longauerová and A. Gubka, "Distribution of Two Invasive Pests in Slovakia since 1996," In: H. Evans and T. Oszako, Eds., Alien Invasive Species and International Trade, Proceedings, IUFRO UNIT 7.03.12, Jedlnia, pp. 105-113.

[28] A. Kunca, R. Leontovyč, M. Zúbrik and A. Gubka, "Bark Beetle Outbreak on Weakened Ash Trees and Applied Control Measures," In: Bulletin OEPP/EPPO Bulletin: Revue des Aspects Réglementaires de la Protection des Végétaux/A Journal of Regulatory Plant Protection, 2011, 
pp. 11-13.

[29] J. Galko, "First Record of the Ambrosia Beetle, Xylosan drus Germanus (Blandford, 1894) (Coleoptera: Curculi- onidae, Scolytinae) in Slovakia," Forestry Journal, Vol. 58, No. 4. 